\title{
The Association Between Dietary Patterns and Insulin Resistance: A Systematic Review
}

\author{
Tayebeh Doostvandi ${ }^{1}$, Hassan Mozaffari-Khosravi ${ }^{2}$, Parvin Mirmiran ${ }^{3,}$, Zahra Bahadoran $^{3}$ \\ ${ }^{1}$ International Campuse, Shahid Sadoughi University of Medical Sciences, Yazd, Iran \\ ${ }^{2}$ Department of Nutrition, Shahid Sadoughi University of Medical Sciences, Yazd, Iran \\ ${ }^{3}$ Nutrition and Endocrine Research Center, Research Institute for Endocrine Sciences, ShahidBehesh ti University of Medical Sciences, \\ Tehran, Iran
}

\section{Email address:}

mirmiran@endocrine.ac.ir (P. Mirmiran)

\section{To cite this article:}

Tayebeh Doostvandi, Hassan Mozaffari-Khosravi, Parvin Mirmiran, Zahra Bahadoran. The association Between Dietary Patterns and Insulin Resistance: A Systematic Review. International Journal of Nutrition and Food Sciences. Special Issue: Nutrition and Cardiometabolic Risk Factors. Vol. 5, No. 1-2, 2016, pp. 14-18. doi: 10.11648/j.ijnfs.s.2016050102.13

\begin{abstract}
Background: Insulin resistance (IR) is associated with multiple metabolic disorders, increasing thereby the risk of type 2 diabetes. The systematic review was performed to study the association between dietary patterns and insulin resistance. Method: The study was carried out in database of PubMed, Scopus, Iran Medex and Magiran for the main keywords including diet, insulin, insulin resistance, dietary pattern. Finding: Articles used collected for reviewwere publications until March 2015.Prospective cohort studies and cross sectional studies were selected based on their title, abstract and full text of the materials. After excluding experimental surveys and studies focused on children and randomized clinical trials, required information were extracted. The results show that "Western" dietary patterns rich in red meat, fried and processed dishes, refined cereals and carbohydrate with high glycemic index has statistically significant effects in incidence of insulin resistance. Conclusion: The results of this systematic review indicate that unhealthy food habits rich in trans fatty acids and saturated fatty acids, refined carbohydrate with high glycemic index are related to the insulin resistance, hyperglycemia and risk of type 2 diabetes.
\end{abstract}

Keywords: Diet, Insulin, Insulin Resistance, Dietary Pattern

\section{Introduction}

Insulin resistance (IR) is a patho-physiological condition where the insulin reporter is less sensitive and therefore insulin in a natural dose is not enough to produce normal biological effects. Insulin resistance is a major risk factor for the development of type 2 diabetes, cardiovascular disease and metabolic syndrome [1].

In the USA, the National Health and Nutrition Examination Survey found that $52.1 \%$ obese adolescents had IR [2]. The obesity-associated increase in fatty acids can trigger insulin resistance through intracellular metabolites that activate protein kinas $\mathrm{C}$ (PKC), leading to the activation of serine/threonine kinases that inhibit insulin signaling [3]. Diet seems to play an important role in IR. Nowadays, various aspects of diet, such as fat, carbohydrate, fiber, whole grain and glyscemic index and glycemic load have been related to IR [2]. Traditionally, nutritional epidemiology has examined the relationship between diet and disease by evaluating the effects of single nutrient or specific foods [4]. However in daily life, people consume a variety of foods with complex combinations of nutrients. To carry out nutritional epidemiological research with more closely models on human experience, researchers have proposed studying dietary patterns rather than isolated foods. This approach can help us to more accurately understand the links between food consumption and the spread or prevention of chronic disease [1].

Therefore, the aim of this review is to study of the association between dietary pattern and insulin resistance.

\section{Material and Methods}

\subsection{Search Strategy}

This paper reviews the articles including cohort and cross sectional studies that published until 2015 in all journals, 
using scientific database, including PubMed, Scopus, Iran Medex and Magiran, using keywords which included: insulin, insulin resistance, dietary pattern, diet and other related key words.

\subsection{Inclusion and Exclusion Criteria}

All studies were selected based on their title, abstract and full text of the materials. The experimental and children studies, case control, clinical trial and duplicate article were excluded. Information obtained from different studies (Table 1) is based on following item respectively: a authors, country, sex, age, sample size, follow up period, dietary intake assess, dietary pattern, result and adjustment variable and primary results of data base search revealed over390 papers in pubmed regarding insulin resistance and dietary pattern. From 2749 articles in scientific data bases, there were 1087 on the subject of diets and insulin resistance. After comprehensive review of title, abstracts and the main objectives of studies 12 article were included in this study (Fig. 1).

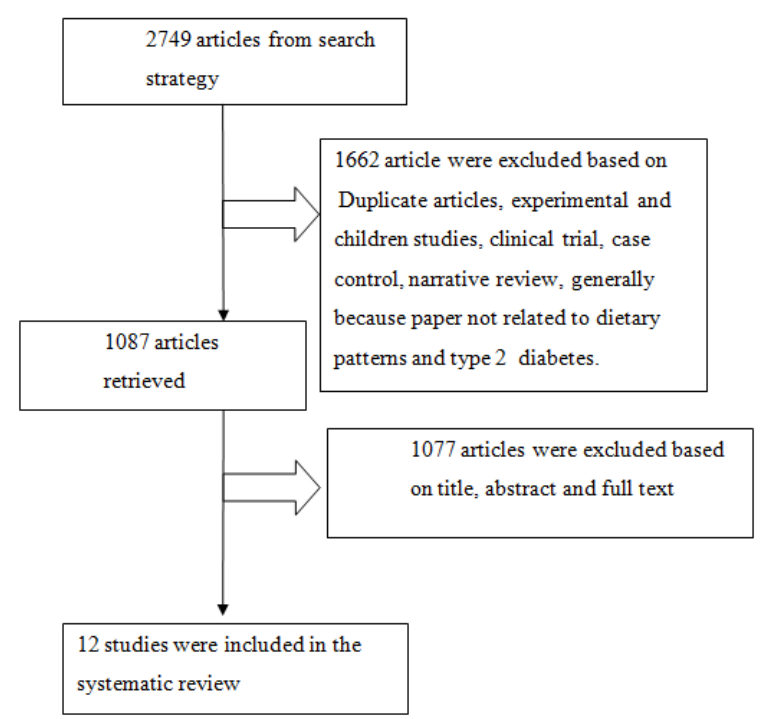

Figure 1. Flow chart of the study.

Table 1. Description of studies of dietary patterns identified via the systematic review.

\begin{tabular}{|c|c|c|c|c|c|c|c|c|c|}
\hline Author & $\begin{array}{l}\text { Country } \\
\text { (year) }\end{array}$ & Sex & $\begin{array}{l}\text { Age } \\
\text { (year) }\end{array}$ & $\begin{array}{l}\text { Sample } \\
\text { size }\end{array}$ & $\begin{array}{l}\text { Follow } \\
\text { up } \\
\text { period } \\
\end{array}$ & $\begin{array}{l}\text { Dietary } \\
\text { intake } \\
\text { assess } \\
\end{array}$ & Dietary pattern & Result & adjustment variable \\
\hline $\begin{array}{l}\text { Arisawa et } \\
\text { al } 2014\end{array}$ & $\begin{array}{l}\text { Japan } \\
(2008)\end{array}$ & $\begin{array}{l}\text { Male } \\
\text { and } \\
\text { females }\end{array}$ & $35-70$ & 513 & $\begin{array}{l}\text { Cross- } \\
\text { sectional }\end{array}$ & FFQ & $\begin{array}{l}\text { PrudentHigh } \\
\text { fat/westernBread and } \\
\text { dairy productsSeafood }\end{array}$ & $\begin{array}{l}\text { High fat/western dietary } \\
\text { pattern was positively } \\
\text { correlated with insulin } \\
\text { resistance in Japanese } \\
\text { population. }\end{array}$ & $\begin{array}{l}\text { Age, sex, smoking, } \\
\text { drinking, physical } \\
\text { activity, total energy } \\
\text { intake }\end{array}$ \\
\hline $\begin{array}{l}\text { Batis et } \\
\text { al., } 2014\end{array}$ & $\begin{array}{l}\text { China } \\
(2009)\end{array}$ & $\begin{array}{l}\text { Male } \\
\text { and } \\
\text { females }\end{array}$ & $27-68$ & 4096 & 15 years & $\begin{array}{l}\text { 24- hour } \\
\text { recalls,Hou } \\
\text { sehold } \\
\text { food } \\
\text { inventory }\end{array}$ & $\begin{array}{l}\text { High in } \\
\text { wheatproducts and } \\
\text { soy milk and low in } \\
\text { rice, legumes, poultry, } \\
\text { eggs, and fish }\end{array}$ & $\begin{array}{l}\text { Dietary pattern trajectories } \\
\text { with healthier scores } \\
\text { Longitudinally had a lower } \\
\text { HbA1c compared to those } \\
\text { with unhealthier scores. }\end{array}$ & $\begin{array}{l}\text { Age, sex, geographic } \\
\text { city, physical activity, } \\
\text { BMI smoking }\end{array}$ \\
\hline $\begin{array}{l}\text { Abiemo et } \\
\text { al., } 2013\end{array}$ & $\begin{array}{l}\text { USA } \\
(2000)\end{array}$ & $\begin{array}{l}\text { Male } \\
\text { and } \\
\text { females }\end{array}$ & $45-84$ & 5390 & $\begin{array}{l}\text { Cross- } \\
\text { sectional } \\
6 \mathrm{yr} \\
\text { follow } \\
\text { up }\end{array}$ & $\begin{array}{l}\text { FFQ } 127 \\
\text { items }\end{array}$ & Mediterraneandiet & $\begin{array}{l}\text { Mediterranean-style diet, } \\
\text { reflected by a higher } a \\
\text { prioriMediterranean diet } \\
\text { score, was cross-sectional } \\
\text { associated with lower insulin } \\
\text { levels among non- } \\
\text { diabetics,and lower blood } \\
\text { glucose prior to adjustment } \\
\text { for obesity, but not with } \\
\text { lower incidence ofDiabetes. }\end{array}$ & $\begin{array}{l}\text { Age, sex, smoking, } \\
\text { physical activity, } \\
\text { family income, } \\
\text { education level, race, } \\
\text { waist circumference }\end{array}$ \\
\hline $\begin{array}{l}\text { Zuo et al., } \\
2013\end{array}$ & $\begin{array}{l}\text { China } \\
(2006)\end{array}$ & $\begin{array}{l}\text { Male } \\
\text { and } \\
\text { females }\end{array}$ & $>18$ & 1070 & $\begin{array}{l}\text { Open } \\
\text { ongoing } \\
\text { cohort } \\
\text { from } \\
2006\end{array}$ & $\begin{array}{l}\text { Semi- } \\
\text { quantitativ } \\
\text { eFFQ }\end{array}$ & $\begin{array}{l}\text { WesternHigh wheat, } \\
\text { Traditional,Hedonic }\end{array}$ & $\begin{array}{l}\text { Dietary pattern were } \\
\text { significantly associated with } \\
\text { insulin resistance }\end{array}$ & $\begin{array}{l}\text { Age, sex, BMI, } \\
\text { smoking, physical } \\
\text { activity, total energy }\end{array}$ \\
\hline $\begin{array}{l}\text { Song et } \\
\text { al., } 2012\end{array}$ & $\begin{array}{l}\text { South } \\
\text { Korea } \\
(2007)\end{array}$ & $\begin{array}{l}\text { Male } \\
\text { and } \\
\text { females }\end{array}$ & $30-65$ & 3871 & 1 year & FFQ & $\begin{array}{l}\text { Diverse diet, western } \\
\text { diet, whole grain and } \\
\text { beans, white rice and } \\
\text { kimchi,alcohol and } \\
\text { coffee }\end{array}$ & $\begin{array}{l}\text { Whole grains and beans } \\
\text { patterns were inversely } \\
\text { associated with insulin } \\
\text { resistance. }\end{array}$ & $\begin{array}{l}\text { Age, sex, education, } \\
\text { income, BMI, } \\
\text { smoking, alcohol use, } \\
\text { physical activity }\end{array}$ \\
\hline $\begin{array}{l}\text { McNaught } \\
\text { on et al., } \\
2008\end{array}$ & $\begin{array}{l}\text { UK } \\
(1988)\end{array}$ & $\begin{array}{l}\text { Male } \\
\text { and } \\
\text { females }\end{array}$ & $\begin{array}{l}35-55 \\
\text { items }\end{array}$ & 7339 & 19 years & $\begin{array}{l}127 \text { item } \\
\text { FFQ }\end{array}$ & $\begin{array}{l}\text { low calorie/diet soft } \\
\text { drinks, onions, sugar- } \\
\text { sweetened beverages, } \\
\text { burgers and sausages, } \\
\text { crisps andother } \\
\text { snacks, and white } \\
\text { bread and low } \\
\text { consumption of } \\
\text { medium-/high-fiber } \\
\text { breakfast cereals,jam, }\end{array}$ & $\begin{array}{l}\text { Dietary pattern associated } \\
\text { with insulin resistance }\end{array}$ & $\begin{array}{l}\text { Age, sex, energy, } \\
\text { ethnicity, } \\
\text { employment grade, } \\
\text { smoking, alcohol, } \\
\text { physical activity, } \\
\text { BMI, blood pressure }\end{array}$ \\
\hline
\end{tabular}




\begin{tabular}{|c|c|c|c|c|c|c|c|c|c|}
\hline Author & $\begin{array}{l}\text { Country } \\
\text { (year) }\end{array}$ & Sex & $\begin{array}{l}\text { Age } \\
\text { (year) }\end{array}$ & $\begin{array}{l}\text { Sample } \\
\text { size }\end{array}$ & $\begin{array}{l}\text { Follow } \\
\text { up } \\
\text { period }\end{array}$ & $\begin{array}{l}\text { Dietary } \\
\text { intake } \\
\text { assess }\end{array}$ & Dietary pattern & Result & adjustment variable \\
\hline & & & & & & & $\begin{array}{l}\text { French } \\
\text { dressing/vinaigrette, } \\
\text { and whole meal bread }\end{array}$ & & \\
\hline $\begin{array}{l}\text { Lie et } \\
\text { al,2009 }\end{array}$ & USA & $\begin{array}{l}\text { Male } \\
\text { and } \\
\text { females }\end{array}$ & & 2875 & & $\begin{array}{l}\text { FFQ } 126 \\
\text { items }\end{array}$ & $\begin{array}{l}\text { FruitsReduce fat dairy } \\
\text { and whole } \\
\text { grainsRefined grains } \\
\text { and sweetsBeer and } \\
\text { soda }\end{array}$ & $\begin{array}{l}\text { consumption of a diet rich in } \\
\text { fruits, vegetables, whole } \\
\text { grains and reduced fatdairy } \\
\text { protects against insulin- } \\
\text { resistant phenotypes and } \\
\text { displacing these healthy } \\
\text { choices with refined grains, } \\
\text { high-fat dairy, sweet } \\
\text { bakedfoods, candy and } \\
\text { sugar-sweetened soda may } \\
\text { promote insulin-resistant } \\
\text { phenotypes. }\end{array}$ & Age, sex, total energy \\
\hline $\begin{array}{l}\text { Esmaillza } \\
\text { deh et al }\end{array}$ & $\begin{array}{l}\text { Iran } \\
(2007)\end{array}$ & $\begin{array}{l}\text { Females } \\
\text { teachers }\end{array}$ & $40-60$ & 486 & $\begin{array}{l}\text { Cross- } \\
\text { sectional }\end{array}$ & $\begin{array}{l}\text { Semi- } \\
\text { quantitativ } \\
\text { eFFQ } 168 \\
\text { item }\end{array}$ & $\begin{array}{l}\text { Western } \\
\text { Healthy Traditional }\end{array}$ & $\begin{array}{l}\text { High consumption of fruit, } \\
\text { vegetables and legumes is } \\
\text { associated with reduce risk } \\
\text { of insulin resistance and } \\
\text { metabolic syndrome in } \\
\text { tehrani female teachers. }\end{array}$ & $\begin{array}{l}\text { Age,anthropomtry,ph } \\
\text { ysical activity,total } \\
\text { energy,smoking,curre } \\
\text { nt esterogen use and } \\
\text { menopausal staus }\end{array}$ \\
\hline $\begin{array}{l}\text { Isharwal } \\
\text { et } \\
\text { al(2008) }\end{array}$ & $\begin{array}{l}\text { India } \\
2008\end{array}$ & $\begin{array}{l}\text { Male } \\
\text { and } \\
\text { females }\end{array}$ & $18>18$ & 352 & & $\begin{array}{l}\text { 24-hour } \\
\text { food recall }\end{array}$ & & $\begin{array}{l}\text { For prevention and } \\
\text { amelioration of insulin } \\
\text { resistancein Asian Indian } \\
\text { adolescents and young } \\
\text { adults, it is prudentto have } \\
\text { normal BMI and low intake } \\
\text { of }-6 \text { PUFAs. }\end{array}$ & Sex,BMI,total fat \\
\hline $\begin{array}{l}\text { Desmond } \\
\text { E. M. } \\
2000\end{array}$ & UK2000 & $\begin{array}{l}\text { Male } \\
\text { and } \\
\text { females }\end{array}$ & $40-65$ & 802 & $\begin{array}{l}\text { Cross- } \\
\text { sectional }\end{array}$ & $\begin{array}{l}35 \text { item } \\
\text { FFQ }\end{array}$ & $\begin{array}{l}\text { healthy balanced } \\
\text { dietlow intake of fried } \\
\text { foods }\end{array}$ & $\begin{array}{l}\text { dietary pattern which } \\
\text { includes increased fruit } \\
\text { and vegetable consumption } \\
\text { and a reduction in the intake } \\
\text { offatty foods and processed } \\
\text { meat for protection against } \\
\text { theoccurrence of the } \\
\text { metabolic syndrome and } \\
\text { glucoseintolerance. }\end{array}$ & $\begin{array}{l}\text { Sex, age, Socio- } \\
\text { economic group, } \\
\text { BMI, Smoking } \\
\text { status, Alcohol intake } \\
\text { category }\end{array}$ \\
\hline $\begin{array}{l}\text { Villegas } \\
\text { r2004 }\end{array}$ & Irish & $\begin{array}{l}\text { Meal } \\
\text { and } \\
\text { females }\end{array}$ & adults & 1473 & $\begin{array}{l}\text { Cross } \\
\text { sectional }\end{array}$ & FFQ & $\begin{array}{l}\text { Traditional Irish } \\
\text { dietPrudent diet } \\
\text { Alcohol and } \\
\text { convenience food }\end{array}$ & $\begin{array}{l}\text { A prudent diet may be } \\
\text { associated with } \\
\text { enhancedinsulin sensitivity } \\
\text { and a lower risk of type } 2 \\
\text { diabetes }\end{array}$ & $\begin{array}{l}\text { Sex, age, smoking } \\
\text { statues }\end{array}$ \\
\hline $\begin{array}{l}\text { Tzima } \\
\text { n2007 }\end{array}$ & Athens & $\begin{array}{l}\text { Meal } \\
\text { and } \\
\text { female }\end{array}$ & $20-87$ & 3042 & cohort & FFQ & Mediterranean diet & $\begin{array}{l}\text { Adherence to Mediterranean } \\
\text { diet is modeslty associated } \\
\text { with a better } \\
\text { insulinsensitivity, lower } \\
\text { levels of total cholesterol } \\
\text { and lower levels of systolic } \\
\text { blood pressure inOverweight } \\
\text { and obese subjects. This may }\end{array}$ & $\begin{array}{l}\text { Sex, age, BMI, } \\
\text { current } \\
\text { smoking,physical } \\
\text { activity, waist, waist } \\
\text { to hip }\end{array}$ \\
\hline
\end{tabular}

\section{Results and Discussion}

In study by Arisawa et al, 513 subjects without treatment for diabetes participated in the baseline survey of cohort study in Tokushima, Japan. Four dietary patterns extracted were: 1- prudent diet (high intake of vegetables and fruits), 2high fat/western (high intake of fried food, fried dish and meat), 3- bread and dairy products, 4- seafood patterns. Statistical analysis showed that a high fat/western dietary patternsmay be positively associated with insulin resistance in the Japanese population [2].
Inanother study of4096adults by Batis et al, with three to six waves of diet data and biomarkers measured in the China health and nutrition surveys, diet was assessed with three 24hour recalls and a household food inventory. A dietary pattern previously identified with reduced rank regression that positively predicted diabetes in 2006 (high in wheat products and soy milk and low in rice, legumes, poultry, eggs, and fish). Findings suggest that dietary pattern trajectories with healthier scores longitudinally had a lower HbAlc compared to those with unhealthier scores, even when trajectories had similar scores in the end point [5]. Abiemo et al, studied 5390 men and women age, 45-48 years with 6 years follow up in 
MESA; dietary intake was assessed as FFQ. A MeDiet score was created based on intake of 10 food components, vegetables, whole grains, nuts, legumes, fruits, ratio of monounsaturated to saturated fat, red and processed meat, dairy, fish and alcohol. MeDiet was not significantly related to risk of incident diabetes. Greater consistency with a Mediterranean-style diet, reflected by a higher a priori Mediterranean diet score, was cross-sectionally associated with lower insulin levels among non-diabetics, and lower blood glucose prior to adjustment for obesity, but not with lower incidence of diabetes [6]. Zuo et al, studied 1070 men and women, aged $>18$ years who participated in the 2006 phase of the China health and nutrition survey. Dietary intake assessed using a validated FFQ and four dietary patterns were identified: the Western (characterized by animal food, milk, cake, etc), high wheat (high in wheat instead of rice, wholegrain and beef/lamb), traditional (high in eggs, tofu, organ meat, pickled, vegetables, etc) and the hedonic pattern (high in beer, wine and alcohols and fresh vegetables). Statistical analysis showed that western pattern was associated with greater odds of insulinresistant;in contrast, the Hedonic patternwas negatively associated with insulin resistance in Chinese adults[1]. In the Song et al, 3871 men and women 30 - 65 years participated in the Korea National Health and Nutrition Examination Survey, using dietary intake to assess was a validated $\mathrm{FFQ}$, and 5 dietary patterns were identified: Diverse diet, western diet, whole grain and beans, white rice and kimchi (traditional fermented cabbage), alcohol and coffee. A dietary pattern, characterized by high consumption of whole grains, beans and fruits was found to inversely associated with insulin resistance in healthy Korean adults [7]. McNaughton et al, assessed 7,339 participants of the Whitehall II study, measuring dietary intake using a 127item food frequency questionnaire, and the reduced rank regression method to determine dietary patterns, using the homeostasis model assessment of insulin resistance as the intermediate or response variable; the association between the dietary pattern identified and incidence of type 2 diabetes was investigated using Cox proportional hazard regression models. The authors identified a dietary pattern characterized by high consumption of low calorie diet, soft drinks, onions, sugar-sweetened beverages, burgers and sausages, crisps and other snacks, and white bread and low consumption of medium-/high-fiber breakfast cereals, jam, French dressing/vinaigrette, and whole meal bread. Higher dietary pattern scores were associated with increased risk of type 2 diabetes. Result demonstrated that a dietary pattern associated with insulin resistance predicts type 2 diabetes risk after adjustment for a range of confounders [8].

Lieet al used data from the fifth examination cycle of the Framingham Offspring Study. Among 2875 participants without diabetes, they identified four dietary patterns based on the predominant sources of energy: 'Fruits, Reduced Fat Dairy and Whole Grains', 'Refined Grains and Sweets', 'Beer' and 'Soda'. These findings indicatedthat consumption of a diet rich in fruits, vegetables, whole grains and reduced fat dairy protects against insulin-resistant phenotypes and displacing these healthy choices with refined grains, high-fat dairy, sweet baked foods, candy and sugar-sweetened soda may promote insulin-resistant phenotypes[9]. In a crosssectional study by Esmaillzadeh et al, 486 Tehrani female teachers, aged 40-60 y were assessed, and 3 major dietary patterns were identified by factor analysis, the healthy dietary pattern, the Western dietary pattern, and the traditional dietary pattern. These findings indicate that a dietary pattern characterized by high consumption of fruit, vegetables, poultry, and legumes is associated with reduced risk of insulin resistance and the metabolic syndrome in Tehranian female teachers. In contrast, a dietary pattern with high amounts of refined grains, red meat, butter, processed meat, and high-fat dairy products and low amounts of vegetables and low-fat dairy products is associated with a greater risk of the metabolic syndrome [4].

Ishrawe et al, investigated the relationship between dietary nutrients and insulin resistance in352 Asian Indian adolescents and young adults, dietary nutrient intake was (24-hour dietary recall and monthly consumption data) result showed that for prevention and amelioration of insulin resistance in Asian Indian adolescents and young adults, it is prudent to have normal BMI and low intakes of 6 PUFAs [10].

In a cross-sectional study by Desmond E. M, 802 subjects aged 40-65 years were randomly selected, and principal component analysis was used to identify four dietary patterns explaining $31 \times 7 \%$ of the dietary variation in the study cohort. Component 1 was characterized by a healthy balanced diet with a frequent intake of raw and salad vegetables, fruits in summer and winter, fish, pasta and rice and low intake of fried foods, sausages, fried fish, and potatoes. this component was negatively correlated with central obesity, fasting plasma glucose, 120 min non-esterifiesfatty acid and triacylglycerol, and was positively correlated with HDL-cholesterol. It therefore appears to be protective against metabolic syndrome; this component was also negatively associated with the risk of having undiagnosed diabetes, an association independent of age, sex, smoking and obesity. These findings support the hypothesis that dietary patterns are associated with other lifestyle factors and with glucose intolerance and other features of the metabolic syndrome [11].

In a cross-sectional study by Villegas et al, 1018 men and women sampled from 17 general practice lists in the south of Ireland. Three dietary patterns were identified by cluster analysis;traditional Irish diet including white breadand refine cereals, chips, butter, whole milk and dairy products, deserts and sweets and lowest intake of poultry, fish, pasta and rice, prudent diet including high intake of pasta and rice, brown and unrefined cereals, spreads, poultry, fish, low fat and dairyproducts, salad dressing, fruit and vegetables and lowest intake of chips, white bread and refine cereals, butter, high fat dairy, meat, meat products and sweet and Alcohol and convenience pattern including high intake of alcohol, meat, meat products, chips and snacks and the lowest intake, of dessert, fruits, vegetable, brown bread and refined cereal, low fat, dairy products and drink; the results showed that prudent diet may be associated with enhanced insulin sensitivity and 
lower risk of type 2 diabetes [12]. Another study indicated that adherence to Mediterranean diet, high intakes of nonrefined cereals and products, vegetables,legumes, fruits, olive oil, dairy products, fish,pulses, nuts, potatoes, eggs, sweets, poultry, red meat andmeat products, was modestly associated with a better insulin sensitivity, lower levels of total cholesterol and lower levels of systolic blood pressure in overweight and obese subjects. This may suggest that compared to general population, the beneficial effect of this diet in cardiovascular system of excess body weight people is limited [13].

In conclusion, results of this systematic review indicate that unhealthy food habits which is rich in trans fatty acids and saturated fatty acids, refined carbohydrate with high glycemic index is related to the insulin resistance, hyperglycemia and risk of diabetes type 2 .

\section{Acknowledgement}

We would like to acknowledge Ms N Shiva for critical editing of the English grammar and syntax of the manuscript.

\section{References}

[1] Zuo H, Shi Z, Yuan B, Dai Y, Pan X, Wu G, et al. Dietary patterns are associated with insulin resistance in Chinese adults without known diabetes. The British journal of nutrition. 2013 May; 109(9): 1662-9. PubMed PMID: 22989490. Epub 2012/09/20. eng.

[2] Song S, Paik HY, Song Y. High intake of whole grains and beans pattern is inversely associated with insulin resistance in healthy Korean adult population. Diabetes research and clinical practice. 2012 Dec; 98(3): e28-31. PubMed PMID: 23041226. Epub 2012/10/09. eng.

[3] Lazar1 MQaMA. Mechanisms of obesity-associated insulinresistance: many choices on the menu. 2015.

[4] Esmaillzadeh A, Kimiagar M, Mehrabi Y, Azadbakht L, Hu FB, Willett WC. Dietary patterns, insulin resistance, and prevalence of the metabolic syndrome in women. The American journal of clinical nutrition. 2007 Mar; 85(3): 910-8. PubMed PMID: 17344515. Epub 2007/03/09. eng.

[5] Batis C, Mendez MA, Sotres-Alvarez D, Gordon-Larsen P, Popkin B. Dietary pattern trajectories during 15 years of follow-up and $\mathrm{HbAlc}$, insulin resistance and diabetes prevalence among Chinese adults. Journal of epidemiology and community health. 2014 Aug; 68(8): 773-9. PubMed PMID: 24729424. Pubmed Central PMCID: PMC4082755. Epub 2014/04/15. eng.

[6] Abiemo EE, Alonso A, Nettleton JA, Steffen LM, Bertoni AG, Jain A, et al. Relationships of the Mediterranean dietary pattern with insulin resistance and diabetes incidence in the Multi-Ethnic Study of Atherosclerosis (MESA). The British journal of nutrition. 2013 Apr 28; 109(8): 1490-7. PubMed PMID: 22932232. Pubmed Central PMCID: PMC4002212. Epub 2012/08/31. eng.

[7] SuJin Song a H-YPa, YoonJu Song. High intake of whole grains and beans pattern is inverselyassociated with insulin resistance in healthy Korean adultpopulation. 2012.

[8] McNaughton SA, Mishra GD, Brunner EJ. Dietary patterns, insulin resistance, and incidence of type 2 diabetes in the Whitehall II Study. Diabetes care. 2008 Jul; 31(7): 1343-8. PubMed PMID: 18390803. Pubmed Central PMCID: PMC2453656. Epub 2008/04/09. eng.

[9] Liu E, McKeown NM, Newby PK, Meigs JB, Vasan RS, Quatromoni PA, et al. Cross-sectional association of dietary patterns with insulin-resistant phenotypes among adults without diabetes in the Framingham Offspring Study. The British journal of nutrition. 2009 Aug; 102(4): 576-83. PubMed PMID: 19216828. Pubmed Central PMCID: PMC3785063. Epub 2009/02/17. eng.

[10] Black MH, Watanabe RM, Trigo E, Takayanagi M, Lawrence JM, Buchanan TA, et al. High-fat diet is associated with obesity-mediated insulin resistance and beta-cell dysfunction in Mexican Americans. The Journal of nutrition. 2013 Apr; 143(4): 479-85. PubMed PMID: 23343677. Pubmed Central PMCID: PMC3738243. Epub 2013/01/25. eng.

[11] Desmond E. M. Williams ATP, Margaret J. Whichelow, Brian D. Cox, Wareham* NEDaNJ. A cross-sectional study of dietary patterns with glucose intolerance andother features of the metabolic syndrome. British Journal of Nutrition (2000), 1999.

[12] R Villegas AS, MM Collins, A Flynn and IJ Perry*. Dietary patterns in middle-aged Irish men and women defined bycluster analysis. 2004.

[13] Natalia Tzima1 CP, Demosthenes B Panagiotakos*1,3, John Skoumas2 AZ, Christina Chrysohoou2 and, Stefanadis2 C. Mediterranean diet and insulin sensitivity, lipid profile and bloodpressure levels, in overweight and obese people; The Attica study. Lipids in Health and Disease 2007, 6: 22. 2007. 